\title{
AN ASSESSMENT OF OPERATING ROOM ENVIRONMENT AIR CONTAMINATION WITH NITROUS OXIDE AND HALOTHANE AND SOME SCAVENGING METHODS
}

\author{
J.W.R. MCInTyre, ${ }^{*}$ J.T. Purdham, $†$ and H.R. Hosein†
}

\begin{abstract}
EPIDEmIological and laboratory studies 1.2 have indicated that contamination of environmental air with anaesthetic gases and vapours should be eliminated or reduced to as low a level as possible. Insufficient information is available to establish definite standards, but a suggested standard for halothane is $2 \mathrm{ppm}$ and for nitrous oxide $25 \mathrm{ppm} .{ }^{3}$ In 1966 experiments were done for a short period in our hospital with cannisters containing charcoals ${ }^{5}$ and presently Foregger scavenging devices are installed on our anaesthetic machines, to work in association with the wall suction in the operating rooms. The study reported here was done in an operating room used for routine general surgery. It describes the efficacy of methods presently available to us, and is intended to serve as a guide to us in future planning for this problem.
\end{abstract}

\section{SCOPE OF STudY}

The study was designed to evaluate the effectiveness of various methods of scavenging under operating room conditions. The scavenging methods evaluated were:

(1) Waste gases and vapours vented directly to floor level through a plastic corrugated tube from the venting port of the mechanical ventilator, and controlled only by the ventilation of the operating room.

(2) Waste gases and vapours vented via a Foregger scavenging device (7-351-005) to the operating room vacuum system.

(3) Waste gases and vapours vented through a charcoal filter (Protect Filter Foregger 7-365-001) sited where the Foregger scavenging device was located and discharging into the operating room at floor level.

*J.W.R. McIntyre, F.R.C.P.(C), Professor, Dept of Anaesthesia, University of Alberta.

†. Purdham, Ph.D., M.C.I.C., and R. Hosein, M.Sc., C.I.H., Occupational Hygiene Branch, Occupational Health and Safety Division, Alberta Labour.

Financially supported by the Dept. of National Health and Welfare Grant No. 609-1047-40* and performed in collaboration with the Occupational Health and Safety Division, Goverment of Alberta. ${ }^{\dagger}$

499

(4) Waste gases and vapours vented through the charcoal filter, sited immediately prior to the Foregger scavenging device, into the scavenger and thence to the operating room vacuum system.

\section{OPERATING ROOM VENTILATION}

The operating room measured $6.1 \times 6.6 \times 2.7$ metres. The ventilation system was evaluated prior to the start of the project ${ }^{6}$ and further measurements were taken on three successive days during the project. Very little variation was found, The conclusions were:

(1) There was a non-uniformity of the aisflow between diffusers.

(2) There was a non-uniformity of exhaust flow between registers.

(3) The total air supply met the design criteria (15 room changes/hour), but the air exhaust was below design characteristics.

(4) The air distribution patterns were sluggish.

The data for each scavenging method was collected over several days, in order to reduce the effects of variability in the supply and exhaust of air from the operating room. This also helped reduce the variability due to differences in types of operations and patients, giving a fairly good cross-section of each for each scavenging system.

\section{Measuring Apparatus}

A Foregger 410 nitrous oxide analyzer was used to check for high pressure leaks in the gas supply system, before beginning the day's anaesthesia.

Miran 101 nitrous oxide and halothane analyzers were used to measure environmental air samples obtained during the study. Known concentrations of halothane and nitrous oxide were generated inside a calibration chamber to check the calibration of the Miran analyzers.

The Tygon tubing employed for the sampling process was found free of significant adsorptive effect on nitrous oxide and halothane. Other substances likely to be present at certain times in the 
TABLE I

Potential interfering substance $\begin{gathered}\text { Nitrous } \\ \text { oxide Halothane }\end{gathered}$

\begin{tabular}{lcc}
\hline 1,2-Dichlorodifluoromethane & + & - \\
Ethanol & - & + \\
Penthrane & - & - \\
G-400 germicidal detergent & - & + \\
Acoholic savlon & + & + \\
Aeroplast dressing & + & + \\
Betadine solution & - & - \\
Betadine surgical scrub & - & - \\
Benzoin spray & + & + \\
Compound benzoin tincture & + & + \\
VI-Drape adhesive & + & + \\
Solvoplast adhesive remover & - & - \\
\hline
\end{tabular}

+ Interference. - no interference.

operating room atmosphere, unless specific efforts are made to prevent this, were tested for their interference properties on nitrous oxide and halothane measurement using a Miran IA analyzer. The results are summarized in Table 1 , although the extent of the interference is not indicated. All the interferences with nitrous oxide absorbance were caused by aerosols with the exception of compound benzoin tincture, and it is believed that the interference arises from freon propellants. The interference was such that a concentration of $20 \mathrm{ppm}$ dichlorofluoromethane would produce a 2.5 per cent error in measuring $25 \mathrm{ppm}$ nitrous oxide and it was anticipated that this would cause few problems in the experiment.

Interference with halothane determination caused by substances containing alcohols was of greater concern. The interference was such that $12 \mathrm{ppm}$ ethanol caused a 50 per cent error in a measurement of $0.85 \mathrm{ppm}$ halothane. Since we expected to find halothane concentrations below this level when using scavenging systems, it became evident that an alternative method for measuring halothane would be required.

The daily average exposure of individual operating room personnel was measured by absorption of halothane on charcoal tubes (NIOSH approved) using Sipin personal sample pumps. The halothane was subsequently desorbed and quantified by gas chromatography.

\section{Sampling Procedure}

Sample probes for the infra-red analyzer were placed at four points in the room and connected to two infra-red analyzers, placed in series, by means of $\frac{1}{2}$-inch internal diameter Tygon tubing.
The selection of a particular sampling point was made by means of a six-way manifold.

The four probes were positioned at breathing height on the anaesthetic machine, on the lights over the operating table, at the exhaust grille, and at the air supply diffuser.

The first two probes were intended to reflect the potential exposure of the anaesthetist and the surgical team to nitrous oxide and halothane. The samples from the exhaust grille were taken as an indication of the general levels around the room and the samples from below the air diffuser were intended to show if there was any incoming pollution due to outside atmospheric conditions returning exhausted air to the air intake.

Sampling was carried out only while operations were in progress and, therefore, the concentrations found refer to the concentrations in the room under operating conditions. Actual personnel exposure must be modified to take account of reduced exposure between operations when, quite often, many of them were absent from the room and the nitrous oxide concentrations rapidly fell towards zero as the operating room flushed with fresh air (non-recirculating system) supplied at a rate of $1000 \mathrm{cfm}$. Exposure is also reduced during break periods. The study covered 21 days, one day of which was spent in the recovery room. During the remaining 20 days a total of 50 operations representing 140 hours of anaesthesia were monitored.

The nitrous oxide infra-red analyzer is a direct reading instrument and was used to measure niIrous oxide concentrations at each of the four positions every five to fifteen minutes throughoul the course of an operation. Sampling was started after the anaesthetic gases had been turned on and terminated as soon as the patient left the room. Air from each sampling point was allowed to flush through the analyzer for one minute before a reading was taken. Occasionally throughout the day the analyzer was rezeroed, using compressed air.

At an early stage of the project it became evident that the Miran 101 halothane analyzer was not suitable for measuring halothane concentrations in the operating room especially when very low concentrations were being measured. This was due mainly to interference from other materials, especially alcohols used in skin preparation for surgery, and in floor cleaning between operations. The use of the Miran 101 halothane analyzer was therefore discontinued and reliance was placed on other methods as outlined below. 
Halothane concentrations in the operating room were determined by adsorption on charcoal followed by desorption in carbon disulphide and gas chromatographic analysis.

Glass tubes containing activated carbon were connected to SIPIN personal sampling pumps, calibrated to draw air through the tubes at approximately $50 \mathrm{ml} / \mathrm{minute}$. The exact volume of air drawn through a particular tube was determined by the number of pump strokes for that sample. Pumps were carried by both the anaesthetist and the scrub nurse, and the tubes were attached to the collars of their clothing so that the samples obtained approximated the breathing zone.

After the abandonment of the Miran 101 analyzer, area samples were also obtained for halothane using carbon tubes attached to SIPIN per'sonal sample pumps. The pumps and tubes were positioned next to the nitrous oxide sampling probes on the anaesthetic machine and on the lights over the operating table. There was insufficient equipment available to obtain area samples at the exhaust grille and the supply air diffuser.

Charcoal tubes were changed during the "no scavenging" section of the project at a convenient time in proceedings and usually every two to three hours. In the scavenging experiments the samples were obtained over the course of the whole day, to collect sufficient material for analysis. The pumps were switched off between operations. After the sample was obtained, the tubes were capped and labelled and returned to the laboratory for analysis. Halothane was desorbed by shaking for at least 30 minutes with $1 \mathrm{ml}$ of carbon disulphide. Under these conditions the desorption efficiency was determined to be 100 per cent. The solution was then analyzed for halothane content by gas chromatography using a Hewlett Packard 5840 gas chromatograph. The chromatographic conditions were: a six-foot stainless steel tube packed with 3 per cent FFAP on Chromosorb $W$, operated isothermally at $50^{\circ}$ $\mathrm{C}$ at a carrier gas fow rate of $21.5 \mathrm{ml} / \mathrm{minute}$ Detection was by a flame ionization detector, and the detection limit was $3 \mu \mathrm{g}$ halothane $/ \mathrm{ml}$ carbon disulphide. Backup sections of the tubes were also analyzed and there was no evidence of halothane breakthrough.

In the recovery room, nitrous oxide was sampled near the centre of the room using the Miran 101 nitrous oxide analyzer. A halothane sample was obtained in the same place using carbon tube adsorption. Samples for halothane were also obtained by attaching pumps and tubes to two of the nurses in the area.

\section{ANAESTHETIC TECHNIQUE}

A Boyle MS anaesthetic machine with a semiclosed circle absorber system was used and the lungs of all patients were ventilated mechanically at approximately $100 \mathrm{cc} / \mathrm{kg} / \mathrm{min}$ with an Air Shields ventimeter ventilator 200-000-70. Anaesthesia was induced intravenously. The lungs were ventilated with oxygen and the trachea was intubated with a cuffed tracheal tube. When a leak proof system had been established, a flow of nitrous oxide $3 \mathrm{l} / \mathrm{min}$ and oxygen $2 \mathrm{l} / \mathrm{min}$ through a Fluotec halothane vaporizer set at 1.0 per cent was started into the circle. At the end of the operation the anaesthetic system was disconnected when the patient was breathing spontaneously and, at the same time, the gas supply from the anaesthetic machine was discontinued. The same anaesthetist and anaesthetic machine were concerned with all anaesthetics.

\section{RESULTS}

The reduced data for nitrous oxide and halothane under the various scavenging conditions are given in the associated tables.

Data reduction for nitrous oxide was carried out by taking the data set for each day, in each position, as a set of grab samples. It has been shown that air contaminant levels are best described by a lognormal distribution.? It was assumed that these data were part of such a distribution and the daily means are, therefore. geometric means rather than arithmetic means. It was assumed further that the daily means were themselves lognormally distributed, so that the overall mean for the scavenging method is also a geometric mean.

Since the halothane concentrations are full period time-weighted averages, no data reduction is needed to obtain the daily average. The daily means are again assumed to be part of a lognormal distribution, and hence, overall means are geometric means.

The variations in ritrous oxide concentration over the operating table throughout two typical days are shown in Figure 1. During one of these days no scavenging was used and during the other the waste gases were vented to the vacuum system. 
TABLE II

Average Nitrous Oxide Concentrations (PPM) Using Varlous Scavenging

TECHNIQUES

\begin{tabular}{|c|c|c|c|c|}
\hline \multirow[b]{2}{*}{ Scavenging techrique } & \multicolumn{4}{|c|}{ Sample location } \\
\hline & $\begin{array}{l}\text { Anaesthetic } \\
\text { machine }\end{array}$ & $\begin{array}{l}\text { Surgical } \\
\text { spot-light }\end{array}$ & $\begin{array}{l}\text { Exhaust } \\
\text { grille }\end{array}$ & $\begin{array}{l}\text { Under supply } \\
\text { air diffuser }\end{array}$ \\
\hline No Scavenging & 181 & 206 & 175 & 93 \\
\hline $\begin{array}{l}\text { Foregger scavenger to } \\
\text { wall suction }(22 \mathrm{l} / \mathrm{min})\end{array}$ & 23.0 & 19.6 & 17.7 & 10.2 \\
\hline Charcoal filter & 181 & 193 & 164 & 89 \\
\hline $\begin{array}{l}\text { Charcoal filter to } \\
\text { Foregger scavenger to } \\
\text { wall suction }(22 \mathrm{l} / \mathrm{min})\end{array}$ & 27.1 & 21.7 & 17.0 & 10.7 \\
\hline
\end{tabular}

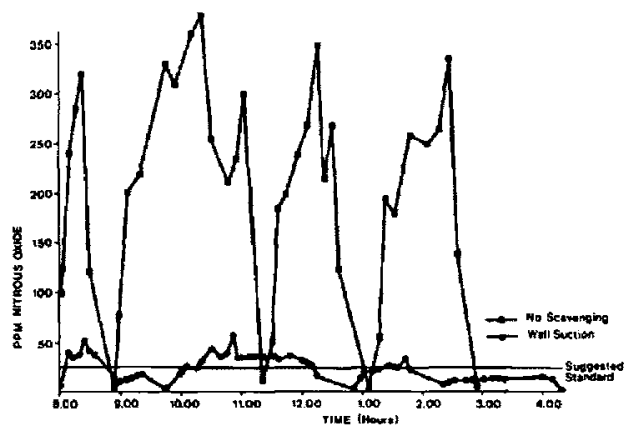

Figure 1. Variations in nitrous oxide concentration over the operating table throughout two typical days. During one of these days no scavenging was used, and this trace shows high peaks of concentration. During the other day the waste gases were vented to the vacuum system.

Inspection of the tables indicates immediately that relying upon the room ventilation alone is not a suitable method for controlling environmental contamination. Nitrous oxide concentrations were found to be six to eight times the suggested standard ${ }^{3}$. Halothane concentrations were over the suggested standard ${ }^{3}$ and it is clear under these conditions of anaesthesia, where halothane constitutes one per cent of the anaesthetic gas, that if the nitrous oxide can be controlled then the halothane is likely to be controlled.

\section{Discussion}

All three methods involving a formal scaveng ing system were successful in reducing halothane concentrations below the recommended concentration of $1 \mathrm{ppm}$ under the conditions of this study. The nitrous oxide concentration, of course, was not reduced by use of the charcoal filter alone, but was reduced by use of the room vacuum to levels approximating the suggested standard of $25 \mathrm{ppm}$. Since these sampling procedures did not include periods of low concentration between patients, the actual time weighted average concentrations will be less than the quoted figures and, therefore, within the control limit. It should be emphasized, however, that the success of the scavenging methods depended on rigorous daily check and correction of high and low pressure leaks in the anaesthesia systems. In addition, great care was taken to minimize spillage of liquids and inadvertent release of nitrous oxide into ambient air.

The use of the Foregger 7-365-001 charcoal filter to control halothane release from the Ohio ventimeter was successful under the the circumstances of this anaesthesia, but these data should not be taken as an endorsement of this product. The ineffectual coupling between the plastic holder and the charcoal containing cannister was a problem. A careful application of plastic tape was necessary to achieve a satisfactory seal. However, there was substantial reduction in halot hane concentrations when the charcoal filter was used alone, many of the samples having no detectable halothane in them. When used in conjunction with the wall suction, however, there appeared to be only little improvement over the use of wall suction alone. A detailed statistical comparison is not warranted since, for many samples, the amount of halothane measured was close to the detection limit and the error in measurement may be quite large. In any future determinations, the flow of the SIPIN pumps should be increased, perhaps to $200 \mathrm{ml} / \mathrm{min}$. Differences in the results when the charcoal cannister was combined with suction scavenging may 
TABLE III

average Halothane Concentrations (PPM) Using Various Scavenging TECHNIQUES

\begin{tabular}{lcccc}
\hline & \multicolumn{4}{c}{ Sample location } \\
\cline { 2 - 5 } & Anaesthetist & $\begin{array}{c}\text { Scrub } \\
\text { nurse }\end{array}$ & $\begin{array}{c}\text { Anaesthetic } \\
\text { machine }\end{array}$ & $\begin{array}{r}\text { Surgical } \\
\text { spot-light }\end{array}$ \\
\hline $\begin{array}{l}\text { Scavenging technique } \\
\text { Foregger scavenger to }\end{array}$ & 2.2 & 2.4 & - & - \\
$\begin{array}{l}\text { wall suction (22 } / / \mathrm{min}) \\
\text { Charcoal filter }\end{array}$ & 0.23 & 0.17 & 0.24 & 0.18 \\
$\begin{array}{l}\text { Charcoal filter to } \\
\text { Foregger scavenger to } \\
\text { wall suction (22 } 1 / \mathrm{min})\end{array}$ & 0.08 & $<0.04$ & $<0.12$ & $<0.06$ \\
\hline
\end{tabular}

have been due to poor sealing associated with the entry of gases to the cannister or alteration in vapour flow patterns in the scavenger reservoir and its safety valves.

When the Foregger scavenging device was in use without a charcoal cannister and connected to the wall vacuum which drew at a rate of approximately $22 \mathrm{l} / \mathrm{min}$, preliminary data suggested that the scavenging device was less effective when large tidal volumes were being delivered to the patient. This could be explained by the volume of gas delivered to the reservoir bag and its compliance, resulting in gas being expelled from the reservoir blow-off valve. This could not be proved with our data, but it still seems reasonable to suggest that the inflow of gas to the circle system and the vacuum should be adjusted so that there is only a small distension of the reservoir bag at the peak of the distending phase. This can be one source of contamination in the anaesthetist's area. The finding that, with no scavenging device in use, the concentration of contaminants was greater at the operating table than at the anaesthetist's position is probably due to the combination of the air flow pattern characteristics of that operating room, and the method of discharge of vented gases and vapours from the anaesthetic equipment. Diffusion from the patient probably played only a small role.

The study reported here was done under specific circumstances of anaesthesia. It can be inferred from our study that, unless it can be shown to the contrary, certain of our operating rooms and our recovery room are often environmentally contaminated to an unacceptable degree with nitrous oxide, halothane, or other halogenated vapour. In certain situations such as gas vapour inductions or in recovery rooms, where
TABLE IV

Nitrous Oxide, and Halothane Concentrations (PPM) IN THE RECOVERY ROOM

\begin{tabular}{lcc}
\hline \multicolumn{1}{c}{ Sample location } & Nitrous oxide & Halothane \\
\hline Near centre of room & 25.0 & 0.17 \\
Recovery room nurse (1) & & 0.28 \\
Recovery room nurse (2) & & 0.15 \\
\hline
\end{tabular}

specific scavenging systems cannot be conveniently and effectively attached to the source of contamination, reliance must be placed on specific patterning of room ventilation ${ }^{3.8 .9}$ if appropriate changes are to occur.

Various aspects of environmental contamination are shown in Table $V$. The fact that most scavenging devices have potential hazards for patients and must be treated circumspectly is most important. It is obvious that most factors are personnel dependent. If anaesthetists and their assistants do not adopt appropriate work habits, if all anaesthetic apparatus including ventilators is not checked regularly and conscientiously for high and low pressure leaks, and if scavenging equipment and environmental ventilation is not working effectively, then a tolerably clear working environment will not be achieved. Probably the most comprehensive guidelines presently available have been published by the U.S. National. Institute of Occupational Health and Safety ${ }^{3,4}$ and adoption of the principles outlined will go far to reduce contamination without elaborate measurement of an exisitng situation before any effort at improvement.

The study reported here did not address the problem of disposal of waste once it has been removed from its source and, depending on the 
TABLE $V$

\begin{tabular}{lll} 
Contamination sources & $\begin{array}{c}\text { Aspects of contamination } \\
\text { reduction }\end{array}$ & $\begin{array}{c}\text { Hazards of anti- } \\
\text { contamination } \\
\text { efforts }\end{array}$ \\
\hline $\begin{array}{l}\text { Anaesthetic apparatus } \\
\text { (including mechanical } \\
\text { ventilators) }\end{array}$ & $\begin{array}{l}\text { Drug selection } \\
\text { Quantity of vented } \\
\text { gases and vapours }\end{array}$ & $\begin{array}{c}\text { Inappropriate } \\
\text { patient care }\end{array}$ \\
$\begin{array}{l}\text { Apparatus circuitry } \\
\text { Patient }\end{array}$ & $\begin{array}{l}\text { Leaks in anaesthetic apparatus } \\
\text { Leaks in anaesthetic circuitry }\end{array}$ & \\
& $\begin{array}{c}\text { Appropriately designed } \\
\text { and functioning scavenging } \\
\text { system }\end{array}$ & $\begin{array}{c}\text { Scavenger } \\
\text { malfunction }\end{array}$ \\
Spillage of drugs & Environmental air exchange \\
& and decontamination & \\
& Care in drug management \\
& Contamination measurement & \\
\hline
\end{tabular}

site of release other parts of the institution may be contaminated or the contaminants may contribute directly to an overall ecological problem. In places where the climate is suitably cold, prior removal of water vapour would facilitate the condensation of effluent halogenated anaesthetics from scavenging or air exchange systems. Rooms that are supplied by a recirculating rather than an air exchange ventilation system pose a difficulty if nitrous oxide is employed and the meticulous use of dedicated scavenging systems becomes even more necessary. Even if that is possible, continuous monitoring of ambient air contamination in these rooms appears to be a necessary safety precaution. In any case a resurgence of interest in low flow and closed circuit anaesthetic systems can be anticipated.

In conclusion, assuming that the principles of careful anaesthetic practice are being followed, the Foregger 410 nitrous oxide monitor appears to be a most useful item of equipment, which can be conveniently calibrated and used to detect high pressure leaks. Techniques that do not require elaborate equipment have been described for the detection of low pressure leaks. Note should be taken of the fact that a dissociation of leak rates between nitrous oxide and halothane can exist, depending on the site of the leak and the design of the anaesthetic apparatus. Systems for continuous monitoring of various gases and vapours from several operating rooms ${ }^{10}$ are attractive, but they are only suitable for large institutions where they can be employed for additional purposes. ${ }^{10}$ In operating rooms where frequent use is made of open inductions, the room ventila- tion commonly found in such locations is unlikely to control contaminants adequately and ventilation control at the source of contamination is the only solution. However, no matter how much care is devoted to the design, selection and installation of equipment to maintain a clean air environment, its value can be nullified by the anaesthetist or technician. This is achieved by failing to check all equipment regularly, failing to use it intelligently and failing to maintain appropriate work practices. Above all, protection of the patient is paramount and the hazards of scavenging devices should be given careful consideration before and during any anaesthetic.

\section{SUMMARY}

This study was designed to assess operating room contamination with nitrous oxide and halothane when nitrous oxide $31 / \mathrm{min}$ and oxygen $2 \mathrm{l} / \mathrm{min}$ containing halothane one per cent were passed into a semiclosed circle absorber system from which the patients' lungs were ventilated with an Ohio ventimeter through a cuffed tracheal tube, with the exhaled gas vented to the floor. The normal room ventilation did not consistently maintain levels below the suggested amounts, which are nitrous oxide $25 \mathrm{ppm}$ and halothane $2 \mathrm{ppm}$. Careful daily check for and correction of high and low pressure leaks combined with the use of a Foregger scavenging device (7-351-005) and continuous wall vacuum accepting approximately $22 \mathrm{l} / \mathrm{min}$ enabled geometric mean values below the suggested levels to be achieved. The Protection Filter Foregger 7-365-001 was only ef- 
fective in removing halothane and only if the plastic holder provided was radically modified. Attention is drawn to the numerous factors influencing the magnitude of contamination, aspects of controlling it, and the necessity to cope with the problem of dealing with scavenged gases and vapours.

\section{RÉSUMÉ}

Le but de cette étude était d'évaluer la contamination de l'atmosphère d'une salle d'opération par des gaz anesthésiques, dans les conditions cliniques suivantes: les malades intubés et ventilés mécaniquement étaient maintenus anesthésiés au moyen d'un mélange de protoxyde d'azote $(31 / \mathrm{mn})$, d'oxygène $(2 \mathrm{l} / \mathrm{mn})$ et d'halothane à 1 pour cent administrés en circuit semifermé.

Si l'on dirigeait les gaz expirés vers le plancher au moyen d'un tube relié à la soupape expiratoire du ventilateur mécanique, la ventilation normale de la salle $n$ arrivait pas à maintenir les concentrations atmosphériques de protoxyde d'azote et d'halothane sous les limites suggérées, à savoir moins de $25 \mathrm{ppm}$ pour le protoxyde d'azote et moins de $2 \mathrm{ppm}$ pour l'halothane.

On a pu obtenir des résultats inférieurs aux limites suggérées au moyen d'un système de vidange Foregger (7-351-005) relié à une succion murale de $22 \mathrm{l} / \mathrm{mn}$. Une vérification soignée quotidienne permettait d'éliminer les fuites de gaz de notre montage anesthésique.

Le filtre à charbon Foregger (7-365-001) était efficace pour éliminer l'halothane seulment et ceci à condition de modifier son support de plastique.

On rappelle des différents facteurs en cause dans la pollution atmosphérique des blocs opératoires par agents anesthésiques, les aspects du contrôle de cette pollution et la nécessité d'attaquer ce problème par la vidange des gaz et des vapeurs anesthésiques.

\section{ACKNOWLEDGEMENT}

Halothane analysis was carried out by the Laboratory Services Branch of Alberta Labour's Occupational Health and Safety Division.

\section{REFERENCES}

1. Occupational disease among operating room personnel: report of an ad hoc commit tee on the effect of trace anaesthetics on the health of operation room personnel. Anesthesiology 41: 321 (1974).

2. Spence, A.A., Cohen, E.N., Brown, Jr, B.W. KNIll-Jones, R.P., Him melbekger, D.U. Occupational hazards for operating room-based physicians. J.A.M.A. 238: 955 (1977).

3. Criteria for a recommended standard - occupational exposure to waste anacsthetic gases and valpours. HEW Publication No. (NIOSH) 77-140. U.S. Department of Health Education and Welfare, Public Health and Safety (1977).

4. Control of occupational exposure to $\mathrm{N}_{2} \mathrm{O}$ in the dental laboratory. HEW Publication No. (NIOSH) 77-171. U.S. Department of Heatth Education and Welfare, Public Health Service for Disease Control. National Institute for Occupational Health and Safety (1977).

5. MCINTYRe, J.W.R.\& RusselL, J.E. Removal and recovery of halothane and methoxyflurane from waste gases. Canad. Anaesth. Soc. J, 14: 333 (1967).

6. Bowhay, D.C., Siegel, H.R., \& Hosein, H.R. Ventilation characteristics of operating room No. 3, University of Alberta Hospital, Edmonton. Occupational Hygiene Branch Report.

7. LEIDEL, N.A.\& BUSCH.K.A. Statistical methods for the determination of noncompliance with occupational health standards. HEW Publication No. (NIOSH) TR-76. U.S. Department of Health and Welfare.

8. Bossers, P.A. Air conditioning in operating rooms. Anaesthesia and Pharmacology, Williams \& Wilkins (1976).

9. WhITCHER, C.H. Controlling occupational exposure to inhalational anaesthetics. Anaesthesia and Pharmacology. Williams \& Wilkins (1976).

10. Severinghaus, J.W. \& Oxanne, G. Multioperating room monitoring with one mass spectrometer. Abstracts 14th Congress Scandinavian Society of Anaesthe siologists (1977). 